\title{
Targeting Poverty through Inclusive Education in Egypt A Review of the Experiences of some Developing Countries
}

\author{
DR. Mahmoud Abdel Hafez Mohamed \\ Assistant Professor of Economics \\ Economics and Public Finance Dept. \\ Faculty of Commerce \\ Kafrelsheikh University, Egypt
}

\begin{abstract}
:
The objective of the present study is to assess educational deprivation and estimate the incidence of multidimensional poverty in Egypt. Poverty alleviation, for both poor and vulnerable groups, should be the most important issue on the agenda of the decision maker because of its relevance for economy and society as a whole. Therefore, this study aims at identifying the most important characteristics that can be relied upon in order to distinguish the poor from the non-poor in Egypt. It also reveals that the main policies that would help in the alleviation of poverty are education reform, activating the role of women in society, paying more attention to rural areas, increasing the role of the private sector in financing the social safety net, and developing an efficient system to target the poor.

Therefore, the present study highlights the role of education in alleviating the incidence of poverty while offering the government some policy recommendations for constructing Poverty Reduction

The main hypothesis on which the present study is based is that inclusive education of good quality is the best means to overcome future learning deficiencies among youth and adults and, consequently, to reduce poverty rates. The methodology used in this research focuses on the analytical inductive method

The present study is divided into three sections. Section 1 provides an overview of poverty trends in Egypt. Section 2 deals with the idea of inclusive education. Section 3 the impact of inclusive education on poverty, In addition, it offers a set of case studies of local and international best practices in the realm of education and business partnerships in educational enterprises.
\end{abstract}

Key words: Poverty, Inclusive Education, Egypt

\section{Introduction:}

The objective of the present study is to assess educational deprivation and estimate the incidence of multidimensional poverty in Egypt... Poverty alleviation, for both poor and vulnerable groups, should be the most important issue on the agenda of the decision maker because of its relevance for economy and society as a whole. Therefore, this study aims at identifying the most important characteristics that can be relied upon in order to distinguish the poor from the non-poor in Egypt. It also reveals that the main policies which would help in the alleviation of poverty are education reform, activating the role of women in society, paying more attention to rural areas, increasing the role of the private sector in financing the social safety net, and developing an efficient system to target the poor. 
Targeting Poverty through Inclusive Education in Egypt...

The present study is divided into three sections. Section 1 provides an overview of poverty trends in Egypt. Section 2 deals with the idea of inclusive education. Section 3 the impact of inclusive education on poverty, In addition, it offers a set of case studies of local and international best practices in the realm of education and business partnerships in educational enterprises.

The main hypothesis on which the present study is based is that inclusive education of good quality is the best means to overcome future learning deficiencies among youth and adults and, consequently, to reduce poverty rates. The methodology used in this research focuses on the analytical inductive method based on available data and information. Moreover, the study relies on recent papers, scientific magazines and books which have dealt with the same subject.

\section{I- Overview of Poverty Trends in Egypt:}

\section{Introduction:}

The aim of this section is to assess poverty in Egypt.. Poverty in Egypt still affects more than one fifth of its population. In order to better understand poverty variations, some tools that can be used in the analysis of poverty in Egypt are hereby presented and maps of poverty in rural and urban areas are provided.

\section{1- Poverty Trends in Egypt:}

\section{1-1- Poverty, especially extreme poverty, remains a major challenge for Egypt:}

Approximately 17.6 million people in Egypt, or 22 percent of the Egyptian population, are not able to satisfy their basic food and non-food needs. The depth of poverty is measured by the poverty gap index, which captures the percentage of people falling below the poverty line in relation to the whole population.

Table No. (1)

Indicators of Poverty in Egypt 2008/2009

\begin{tabular}{l|c|c|c|c|c|c|c|c|c}
\hline \hline & \multicolumn{3}{|c|}{$\begin{array}{c}\text { Percent of people } \\
\text { below }\end{array}$} & \multicolumn{3}{c|}{$\begin{array}{c}\text { Poverty gap (p1) for } \\
\text { those below }\end{array}$} & \multicolumn{2}{c}{$\begin{array}{c}\text { Squared poverty gap (p2) } \\
\text { for those below }\end{array}$} \\
\hline & $\begin{array}{c}\text { Extreme } \\
\text { (food) } \\
\text { line }\end{array}$ & $\begin{array}{c}\text { Lower } \\
\text { poverty } \\
\text { line }\end{array}$ & $\begin{array}{c}\text { Upper } \\
\text { Poverty } \\
\text { Line }\end{array}$ & $\begin{array}{c}\text { Extreme } \\
\text { (food) } \\
\text { line }\end{array}$ & $\begin{array}{c}\text { Lower } \\
\text { poverty } \\
\text { line }\end{array}$ & $\begin{array}{c}\text { Upper } \\
\text { Poverty } \\
\text { Line }\end{array}$ & $\begin{array}{c}\text { Extreme } \\
\text { (food) } \\
\text { line }\end{array}$ & $\begin{array}{c}\text { Lower } \\
\text { poverty } \\
\text { line }\end{array}$ & $\begin{array}{c}\text { Upper } \\
\text { Poverty } \\
\text { Line }\end{array}$ \\
\hline Urban & 2.6 & 10.6 & 24.6 & 0.4 & 1.9 & 5.4 & 0.1 & 0.5 & 1.8 \\
\hline Rural & 9.6 & 30.0 & 52.7 & 1.5 & 5.9 & 12.8 & 0.4 & 1.8 & 4.5 \\
\hline Total & 6.7 & $22.0 * *$ & 41.2 & 1.1 & 4.2 & 9.8 & 0.3 & 1.3 & 3.4 \\
\hline \hline
\end{tabular}

Source: World Bank (2011) Report No. 60249-EG. Arab Republic of Egypt Poverty in Egypt 2008-2009, Washington, D.C., p. 32-36.

* P0 is a measure of incidence of poverty; P1 measures the depth of poverty and P2 measures the severity of poverty (Foster; Green and Thorbecke, 1984).

**Note: the number of poor includes the extreme poor

Table (1) indicates that extreme poverty, i.e., the inability to satisfy basic food needs, reached by 2008/09 its highest level in the last 15 years: 6.7 percent on average, with a peak of 9.6 percent in rural areas. This means that in 2008/09 5.1 million Egyptians were severely incapable of meeting their basic need for food. In addition, 4.6 million of them lived in rural areas. Overall, around 16 million were below the lower poverty line, and 30 million below the upper poverty line. 
More than half of the population in rural areas remains poor and near poor-a share which has been stable over the last 15 years. While poverty in the country appears to be shallow (the monetary deficit of a poor person is just above one Egyptian pound), there are pockets of deep poverty, particularly in rural areas, that are cases for major concerns.

The poverty gap measure in Egypt ( $\mathrm{P} 1=1.1$ percent for the food poverty line, 4.2 percent for the lower poverty line) implies that, on average, an extremely poor person is 16 percent below the food poverty line while an average poor person is 19 percent below the lower poverty line in terms of daily per capita values. This translates into a deficit of just LE1.17 for a medium poor person to attain the poverty standard, which in turn indicates that, on average, poverty remains shallow. However, given the concept of average per se, there are many poor people who fall way below that average gap and there are pockets of deep poverty. Table (2) provides, a very sensitive indicator of the existence of such pockets by showing the index of poverty severity (squared poverty gap). The table reveals that poverty severity in rural areas is three times higher than in urban ones.

Table No. 2

Poverty Incidence by Region, 2008/2009

\begin{tabular}{l|c|c|c|c|c|c|c}
\hline \hline & \multicolumn{3}{|c|}{ Headcount Rates(P0) } & \multicolumn{3}{c|}{ Distribution of } & $\begin{array}{c}\text { Distribution of } \\
\text { Population }\end{array}$ \\
& $\begin{array}{c}\text { Extreme } \\
\text { food) } \\
\text { Poverty }\end{array}$ & poverty & $\begin{array}{c}\text { Near } \\
\text { Poverty }\end{array}$ & $\begin{array}{c}\text { Extreme } \\
\text { Poor }\end{array}$ & Poor & $\begin{array}{c}\text { Near } \\
\text { Poor }\end{array}$ & \\
\hline \hline Metropolitan & 1.1 & 6.0 & 10.3 & 2.8 & 4.6 & 9.1 & 17.0 \\
Lower Urban & 0.7 & 6.8 & 14.2 & 1.2 & 3.6 & 8.6 & 11.5 \\
\hline Lower Rural & 2.7 & 16.6 & 21.8 & 12.5 & 24.0 & 36.1 & 31.8 \\
Upper Rural & 6.8 & 21.7 & 19.7 & 11.6 & 11.3 & 11.8 & 11.5 \\
\hline Upper Rural & 18.1 & 46.1 & 23.9 & 71.5 & 55.8 & 33.2 & 26.6 \\
Borders Urban & 1.0 & 4.5 & 10.9 & 0.1 & 0.2 & 0.6 & 1.0 \\
\hline Borders Rural & 4.3 & 20.5 & 24.4 & 0.3 & 0.5 & 0.7 & 0.5 \\
\hline Total & 6.7 & 22.0 & 19.2 & 100.0 & 100.0 & 100.0 & 100.0 \\
\hline \hline
\end{tabular}

Source: World Bank (2011) Report No. 60249-EG. Arab Republic of Egypt Poverty in Egypt 2008-2009,

Washington, D.C., p21

Note: Poverty column Includes poor and extreme poor.

\section{1-2- The Evolution of poverty between $2004 / 05$ and 2008/09}

Egypt experienced a remarkable economic growth, which reached the peak of $7.1 \%$ in 2006-07 and was accompanied by a rapid increase in exports and FDI inflows.

However the promotion of strong economic growth and market-oriented economic reforms without a re-distribution of income, were not sufficient to address Egypt's main socio-economic challenges (Achcar, G. 2009). Therefore, in spite of its outstanding macroeconomic performance, a large part of Egyptians, especially from the lower-middle class, experienced a dramatic increase in hardship. This meant that most Egyptians did not benefit from the rapid economic growth. 
Targeting Poverty through Inclusive Education in Egypt...

The reasons for the ineffectiveness of economic and social policies in Egypt to address the country's main socio-economic challenges are to be found in political factors//are of political nature... Indeed, economic reforms served the interests of the ruling elite and their close associates, allowing them to reinforce their power while excluding the rest of the population. In doing so, they perpetuated economic inefficiencies, hindered the emergence of an autonomous, competitive and productive private sector and led to widespread corruption.

Over the last decade, the diminishing purchasing power of the poor Egyptians which had characterized the previous years, was significantly reversed (Klau, A.2010).

This inflationary trend did not affect evenly the entire population but rather had a disproportionate effect on middle and lower income classes, who spend a large share of their income on food items. Soaring food prices were the main cause of rising income poverty over the last decade. In particular, the incidence of absolute poverty increased from $16.7 \%$ in 200001 to $22 \%$ in 2008/2009, reversing the gains made in the second half of the 1990 s.

Over the last two decades, labour market problems worsened dramatically also among the young educated Egyptians. Although in the last ten years the total rate of unemployment improved, youth unemployment among university graduates increased (from 9.7\% in 1998 to $14.4 \%$ in 2006) (Kheir-El-Din,2006) The present study provides a direct comparison of two rounds (2004/05 and 2008/09) of cross-sectional data and examines the main definitions of poverty and living standards for each period. It finds that the gains achieved during the period of sustained growth were reversed. As a result, poverty actually increased between 2004/05 and 2008/09, passing from 19.6 to 22 percent of the population.

Table(3) compares overall poverty rates for the two periods.

Table No.3

Poverty Incidence by Region, 2008/2009

\begin{tabular}{l|c|c|c|c|c|c|c|c}
\hline \hline \multicolumn{1}{l}{ Headcount Rates (P0) } \\
\hline & \multicolumn{1}{c|}{ Extreme (food) } & \multicolumn{2}{c|}{ Poverty } & \multicolumn{2}{c}{ Near Poverty } & \multicolumn{2}{c}{ Inequality(Gini) } \\
\hline & $\mathbf{2 0 0 4 / 0 5}$ & $\mathbf{2 0 0 8 / 0 9}$ & $\mathbf{2 0 0 4 / 0 5}$ & $\mathbf{2 0 0 8 / 0 9}$ & $\mathbf{2 0 0 4 / 0 5}$ & $\mathbf{2 0 0 8 / 0 9}$ & $\mathbf{2 0 0 4 / 0 5}$ & $\mathbf{2 0 0 8 / 0 9}$ \\
\hline Urban & 1.7 & 2.6 & 10.1 & 10.6 & 15.9 & 14.0 & 34.0 & 33.3 \\
\hline Rural & 5.4 & 9.6 & 26.8 & 30.0 & 24.9 & 22.8 & 22.0 & 21.6 \\
\hline Total & 3.8 & 5.7 & 19.6 & 22.0 & 21.0 & 19.2 & 31.3 & 30.7 \\
\hline \hline
\end{tabular}

Source: World Bank (2011) Report No. 60249-EG. Arab Republic of Egypt, Poverty in Egypt 2008-2009,

Washington, D.C., p. 23.

Note: Poverty column Includes poor and extreme poor.

The results show that in February 2008 poverty and near poverty (but not extreme poverty) had fallen by nearly 20 percent compared to the levels of February 2005 . However, the poverty reduction gains realized during three years of high growth, February 2005 to February 2008, and documented in the previous W.B report (World Bank, 2011), seem to have been quickly eroded by the end of 2008, following the global food prices increase and global economic crisis. The increase in poverty rates was not the same for all different types of poor subjects, with the extreme poor being affected the most. The poorest were hit the hardest, and extreme poverty increased from 3.8 to $6.7 \%$. 
The incidence of near poverty, on the other hand, decreased. The risk of poverty (when netting out extreme poverty) dropped in both urban and rural areas, due to population growth and the increasing extreme poverty rate. Overall, the number of poor subjects increased by 3 million people (to 16.5 million), out of which 2.4 million were the new extreme poor. Ironically, Table (3) also suggests that, despite the distributional change in relation to the extreme poor, inequality decreased (as shown by a borderline, statistically significant fall in the Gini index). This fall in inequality is in sharp contrast with 2005-2008, when inequality increased.

\section{1-3- Why is rural poverty higher in Upper Egypt than in Lower Egypt?}

Poverty is higher in rural areas than in urban areas, and particularly high in rural Upper Egypt. Not only is the risk of being poor higher in rural areas (26.8 percent) than in urban areas (13.4 percent, excluding metropolitan areas), but poverty is also more severe in rural areas. Furthermore, poverty is highest in rural Upper Egypt (39.1 percent) and lowest in Metropolitan areas (5.7\%) (World Bank, 2007).

The high level of poverty in rural Upper Egypt may be related in part to the nature of its main economic activity, namely, agriculture.

Almost two thirds of the population of Upper Egypt is engaged in agriculture.. In terms of demography, there exists the highest rate of dependents (children less than 14 years of age in relation to working age adults). Concerning education, Upper Egypt encompasses the highest share of illiterates and the lowest share of university graduates. In terms of employment characteristics, Upper Egypt involves the highest proportion of unpaid workers, the lowest proportion of workers with government and public sector jobs, and the highest proportion of population in agriculture.

With regard to school attendance, the data show (United Nations Development Program, and the Institute of National Planning, 2010) that, in 2008/2009, 5.3\% of children in the whole country aged 6-17 years were employed. Again, the distribution is not even and it reflects the patterns of poverty, with poorer Upper Egypt experiencing a higher number of children in the workforce. Childhood poverty ranges from a low of $6.6 \%$ in the metropolitan region to $41.4 \%$ in rural Upper Egypt; when both parents do not work; poverty-related risks have twice a chance of afflicting families than they do when both parents are employed.

\section{2- Child Poverty in Egypt}

The UNICEF report on child poverty in Egypt (UNICEF, 2010) indicates that almost half of the children $(47 \%)$ in income poor households experience at least one severe deprivation out of seven dimensions (health, education, shelter, nutrition, water, sanitation and information) compared to $14 \%$ of non-poor children. In addition, the gap of children who suffer from deprivation between the poor and non-poor, measured in terms of income, is wider when we consider children suffering from at least two severe deprivations (absolute poverty). The percentage of children experiencing at least two or more deprivations is $10 \%$ for the income poor and only one percent for the non-income poor" (UNICEF, 2009).

The percent of the Egyptian youth, aged 18-29, who suffer from different severe deprivations of basic human needs, shows that education deprivation is the most prevalent and severe for this category, of whom 17\%, accounting for over 3 million, have never been to school or have not completed their primary education. Under these circumstances, many of them are virtually illiterate and, in the absence of adequate vocational training facilities, these children pass into adolescence with very poor skills and capabilities. 


\section{II- Inclusive Education: Introduction:}

Egypt considers education a foundation of national security. However, despite the evident and notable progress in increasing the number of students, there are still many challenges facing education in the country. One of these challenges is illiteracy which is still pervasive, in particular among women. The year of 2006 revealed that the number of illiterates was 16.8 million people, or close to a third of the adult population. There is concern over consistently high figures shown in an increasing number of school dropouts; a low rate of enrollment at the pre-school level; and a high number of unemployed graduates due to lack of linkages between education and the job market.

Inclusive education of good quality is the best means to overcome future learning deficiencies among youth and adults in today's status quo. This section will discuss some of these challenges and the reform initiatives implemented in an effort to meet them, as well as the strategies and some priority areas to be considered in the future.

\section{- Definition of Inclusive education:}

There are various definitions of inclusive education, and there is no universally agreed upon understanding of it. Inclusive education is a process of strengthening the capacity of the education system to reach out to all learners and can thus be understood as a key strategy to achieve EFA. As an overall principle, it should guide all education policies and practices, starting from the fact that education is a basic human right and the foundation for a more just and equal society.

UNESCO, in 2006 (UNESCO, 2006) described inclusive education as a process of addressing and responding to the diversity of the needs of all learners through inclusive practices in learning, cultures and communities and reducing exclusion within and from education. It involves changes and modifications in content, approaches, structures and strategies, with a common vision, which covers all children of the appropriate age range and a conviction that it is the responsibility of the regular system to educate all children.

\section{- Inclusion of the Poor through Education:}

A low rate of educational attainment remains one of the key determinants of poverty.

In 2007, Almost $80 \%$ of the poor population (equivalent to $16 \%$ of all Egyptians) had only basic education or lower (half of them are illiterate), while only $3.4 \%$ had higher-than-average degree. Poverty among individuals with low education was slightly less concentrated in 2005 compared to 2000 , with corresponding figures being $86 \%$ and $1.9 \%$, respectively. Yet, there were still wide disparities in the educational attainment between the poor and near poor, on one hand, and the better off, on the other. Moreover, these disparities were more pronounced in urban areas than in rural areas; more specifically, educational gaps between the poor and the better off in urban areas were the highest: the difference in illiteracy rates was as large as 17 percentage points in favor of the non-poor, and the urban non poor had many more university graduates among them (by 14 percentage points).

Consequently, education can be seen as a powerful shield against poverty, especially in urban areas. Similarly to what is observed in other countries, higher educational attainment is 
associated with lower poverty incidence. At the national level, in 2005 the probability of being poor dropped significantly for individuals with read-and-write skills (20\%) compared to illiterates $(26.8 \%)$.

However, the premium for an individual to have a basic education relative to read- andwrite skills is practically zero. The most significant difference appeared to kick in at higher levels of education with a 5\% risk for university graduates to be poor. Not only was poverty the highest for illiterate individuals in every region, but it was also the deepest and most severe. (See Table 4).

Table No. 4

Poverty Is the Highest, Severest and Deepest for Illiterates

\begin{tabular}{l|c|c|c|c|c|c|c}
\hline \hline \multirow{2}{*}{ Education of all adults } & Illiterate & \multicolumn{2}{|c|}{$\begin{array}{c}\text { Read and write } \\
\text { Primary/p }\end{array}$} & \multirow{2}{*}{ Secondary } & Diploma & Higher & $\begin{array}{c}\text { All } \\
\text { adults }\end{array}$ \\
\cline { 3 - 8 } & & write & rep & & & & \\
\hline \hline Poverty indicators & $26.8 \%$ & $20.0 \%$ & $20.1 \%$ & $14.0 \%$ & $8.5 \%$ & $5.0 \%$ & $19.8 \%$ \\
\hline P0- headcount & $5.5 \%$ & $3.7 \%$ & $3.8 \%$ & $2.5 \%$ & $1.5 \%$ & $0.7 \%$ & $3.6 \%$ \\
\hline P1- depth & $1.6 \%$ & $1.0 \%$ & $1.1 \%$ & $0.7 \%$ & $0.4 \%$ & $0.2 \%$ & $1.0 \%$ \\
\hline \hline
\end{tabular}

Source: World Bank (2007), Arab Republic of Egypt, Poverty Assessment Update, Main Report, 16, September.

This was even more obvious in urban areas than in rural areas. Poverty measures for the illiterate were 1.7 times higher than the overall average in the Metropolitan region, while they were 1.4 and 1.2 times higher respectively in urban and rural areas, confirming a stronger relationship between poverty and education in urban areas compared to rural areas.

\section{3- Education and Competitiveness in the Global Economy:}

Education is the bedrock of competitiveness. Most developed countries have already made the shift to a service economy with fewer jobs in manufacturing and more in information services. Therefore, it is essential to foster education initiatives that address the intricate relationship between human capital and the labor market. Economic success is increasingly based on the effective utilization of intangible assets, such as knowledge, skills, and innovative potential, as the key resource for competitive advantage.

The decline in the quality of education is perhaps the most serious challenge that threatens the educational process in Egypt. The rising enrollments and limited resources for education at the primary and secondary levels have forced schools to enlarge class capacities which have had a negative impact on the quality of education and future employment prospects of the youth who are ill-prepared for the labour market. The current education system has also missed out on the promotion of a curriculum in line with the demands of the labor market and has exacerbated inequalities between the well-off who can afford private education and the poor who cannot.

This tendency has moved in tandem with supply side changes reflected in the increased emphasis on higher education and a demand driven higher education system that responds to the skills needed by the new economic system. While the theories of new growth suggest that developing nations have better chances of catching up when they have a workforce that can develop new technologies or can adopt and use foreign technology, in the case of Egypt one finds that its competitive performance is hampered by the low attainment of higher education and the lack of competitive industries capable of absorbing the oversupply of graduates and skilled workforce. 
Targeting Poverty through Inclusive Education in Egypt...

Another obstacle is the strong preference for education that prepares for administrative careers. About $64 \%$ of students enrolled in Egyptian universities in the academic year 2007/2008 were enrolled in social studies (commerce, law, arts and education). Those enrolled in engineering, medicine, pharmacy and science have a limited share in the total numbers of students, representing $17.6 \%$ of students enrolled. The same holds true for graduates of applied sciences who represent about $15.2 \%$ of the total percentage of graduates

Table No. 5

Some Indicators

\begin{tabular}{l|c|c|c|c|c|c|c|c|c|c}
\hline \hline \multicolumn{1}{c|}{ Indicator } & \multicolumn{2}{|c|}{ Egypt } & \multicolumn{2}{c|}{ Brazil } & \multicolumn{2}{c|}{ Malaysia } & \multicolumn{2}{c|}{ Turkey } & \multicolumn{2}{c}{ Best Performer } \\
\hline \hline Tertiary enrollment & $\begin{array}{c}\text { Rank/ } \\
\mathbf{6 2}\end{array}$ & Value & $\begin{array}{c}\text { Rank } \\
\mathbf{6 2 2}\end{array}$ & Value & $\begin{array}{c}\text { Rank } \\
\mathbf{1 6 2}\end{array}$ & Value & $\begin{array}{c}\text { Rank } \\
\mathbf{6 2}\end{array}$ & Value & & Value \\
\hline $\begin{array}{l}\text { Quality of math and science } \\
\text { education }\end{array}$ & 44 & 32.4 & 48 & 25.6 & 40 & 40.2 & 36 & 45.8 & Korea, Rep & 103.1 \\
\hline Quality of management schools & 62 & 2.3 & 59 & 2.6 & 10 & 5.0 & 49 & 3.5 & Singapore & 6.3 \\
\hline Extent of staff training & 61 & 3.1 & 24 & 4.4 & 6 & 5.2 & 37 & 4.0 & Switzerland & 5.6 \\
\hline Brain drain. & 60 & 2.2 & 20 & 4.6 & 17 & 4.7 & 45 & 3.4 & Switzerland & 6.3 \\
\hline $\begin{array}{l}\text { Local availability of specialized } \\
\text { research and training services }\end{array}$ & 56 & 3.7 & 27 & 4.8 & 16 & 5.4 & 48 & 4.0 & Switzerland & 6.3 \\
\hline \hline
\end{tabular}

SOURCE: World Economic Forum USA Inc., The Financial Development Report 2012, New York, USA.

In order to identify variables as advantages or disadvantages, the following rules were applied:

- For those economies ranked in the top 10 in the overall Index, individual variables ranked from 1 to 10 are considered to be advantages.

Any variables below 10 are considered disadvantages.

For instance, in the case of Canada, which is ranked 6th overall, its 5th-place rank in the variable Quality of management schools makes this variable a development advantage, whereas Extent of staff training, in which it ranks 17th, constitutes a development disadvantage for the country.

The ability of graduates to apply acquired knowledge to the workplace has not been promising (see table 5). According to an ILO survey, the level of satisfaction of employers with their young recruits is generally fair $(66 \%)$. However, many employers have criticized the low abilities of the young graduates in applying their knowledge (41\% of employers assessed it as poor). The same low ranking is given to the practical training provided to young applicants at school (48\% of employers). The education and training system visibly fails to produce the skills that are required to perform the jobs.

University graduates constitute about $12.2 \%$ of the work force in Egypt, while holders of higher diplomas, M.A. and PhD. Degrees, constitute $0.4 \%$ of the labor force. As for the order of unemployment rates in different fields of specialization, the highest unemployment rate during the period of 2002 to 2004 was in commerce (34.7\%), followed by arts and archeology (about $15.3 \%$ for each), agriculture and law (14.5\% for each), other fields of specialization $(10 \%)$, social work $(7.3 \%)$, and finally engineering $(3.8 \%)$.

Private universities supposedly enhance the quality of graduates since they are fee-based institutions. However, to a large extent, they duplicate public university curricula with no qualitative addition, often using the same pool of teaching staff and attracting students with lower entry grades. Their focus is mainly on engineering, medicine, management and media, 
but they do not contribute to the improvement of the quality of graduates, that is what the labor market demands.

Table No. 6

Economy Profiles Index of Countries

\begin{tabular}{l|c|c|c|c|c|c|c|c|c|c}
\hline \hline & \multicolumn{2}{|c|}{ Egypt, Arab Rep. } & \multicolumn{2}{c|}{ Brazil } & \multicolumn{2}{c|}{ Malaysia } & \multicolumn{2}{|c|}{ Turkey } & \multicolumn{2}{c}{ Best Performer } \\
\hline \multicolumn{1}{c|}{ Indicator } & Value & $\begin{array}{c}\text { RANK/ } \\
\mathbf{1 4 4}\end{array}$ & Value & $\begin{array}{c}\text { RANK/ } \\
\mathbf{1 4 4}\end{array}$ & Value & $\begin{array}{c}\text { RANK/ } \\
\mathbf{1 4 4}\end{array}$ & Value & $\begin{array}{c}\text { RANK/ } \\
\mathbf{1 4 4}\end{array}$ & country & Value \\
\hline $\begin{array}{l}\text { Quality of primary } \\
\text { education }\end{array}$ & 2.1 & 137 & 2.5 & 126 & 4.9 & 24 & 3.3 & 95 & Finland & 6.8 \\
\hline $\begin{array}{l}\text { Primary education } \\
\text { enrollment, net \%* }\end{array}$ & 94.4 & .59 & 94.4 & 60 & 95.9 & 46 & 97.5 & 34 & $\begin{array}{c}\text { Singapore } \\
\text { Japan }\end{array}$ & 100.0 \\
\hline $\begin{array}{l}\text { Secondary education } \\
\text { enrollment, gross \%* }\end{array}$ & 72.5 & 101 & 105.8 & 17 & 68.3 & 103 & 77.6 & 93 & Australia & 131.3 \\
\hline $\begin{array}{l}\text { Quality of the } \\
\text { educational system }\end{array}$ & 2.3 & 139 & 3.0 & 116 & 5.1 & 14 & 3.5 & 82 & Switzerland & 6.0 \\
\hline $\begin{array}{l}\text { Internet access in } \\
\text { schools }\end{array}$ & 3.0 & 116 & 3.7 & 88 & 5.1 & 38 & 4.3 & 68 & Iceland & 6.5 \\
\hline $\begin{array}{l}\text { Availability of } \\
\text { research and training } \\
\text { services }\end{array}$ & 3.7 & 99 & 4.8 & 34 & 5.4 & 17 & 4.0 & 77 & Switzerland & 6.4 \\
\hline \hline
\end{tabular}

SOURCE World Economic Forum, the Global Competitiveness Report 2012-2013, Geneva Copyright @ 2012 by the World Economic Forum (Opinion Survey)

VALUE: This column reports the country's score on each indicator. - RANK/144: This column reports the country's position among the 144 economies covered by the GCI 2012-2013. The ranks of those indicators that constitute a notable competitive advantage are highlighted in blue bold typeface (except for inflation). Competitive advantages are defined as follows: For those economies ranked in the top 10 in the overall GCI, individual indicators ranked from 1 through 10 are considered to be advantages. For instance, in the case of Germany-which is ranked 6th overall-its 7th rank on indicator 1.06 Judicial independence makes this indicator a competitive advantage. For those economies ranked from 11 through 50 in the overall GCI, variables ranked higher than the economy's own rank are considered to be advantages. In the case of Iceland, ranked 30th overall, its rank of 12 on indicator 7.08 Female participation in labor force makes this indicator a competitive advantage.

Although they are increasingly educated, the graduates of this educational system pose serious questions about the quality of education they receive. Nevertheless, some positive changes are taking place. Many new initiatives in both private and public universities have been introduced to enhance the spirit of entrepreneurship, with some programs linked to regional projects. One example is EFHAM, a joint initiative between Cairo University and the Egyptian Junior Business Association, which aims to encourage students to create their own entrepreneurial opportunities. This extra-curricular program introduces the values of risk taking, creative and critical thinking, and civic responsibility. Similarly, the Center for Small and Medium Business at "Helwan University" offers young graduates services and training on how to start up a business and offers access to finance.

A preliminary assessment of most of these initiatives indicates that there is a lack of coordination, follow up and evaluation. Some programs overlap and the route to entrepreneurship remain unclear. Students are engaged in several projects. In addition, 
Targeting Poverty through Inclusive Education in Egypt...

programs lack a clear vision and connectivity to the main stakeholders. Linkage projects are also rare. In this respect, corporate social responsibility can play a significant role in developing a coherent vision, plan of action and programs to enhance the impact of entrepreneurship education., achieving autonomy requires reforms that aim at allowing more freedom in deciding optimal number of students, hiring academic and non-academic staff, and regular assessment and performance-based payment schemes.

\section{4- Challenges for Policy-Makers}

\section{a. Attitudinal Changes and Policy Development}

The lack of understanding, awareness and support of society concerning inclusive education needs to be addressed through advocacy and dialogue at the regional and national levels.

\section{Education Reform at Pre-University Level:}

The quality of education remains a major challenge. There remains the need for reform in order to move from a system with over-concentration on memorizing content, passive pedagogies and inadequate facilities and equipment, to a system where students are active participants in the learning process, with access to efficient teachers, suitable learning material, life skills and social capabilities.

\section{b. Ensuring Inclusion through early Childhood Care and Education}

The right to education must be guaranteed for all children. Children in poor households are highly disadvantaged in literacy, with large regional and gender gaps. Among the children aged 12 to 15 years in Egypt, the illiterate poor in 2005, were 3 times the illiterate non-poor. (See Table 7).

Table No. 7

Percentage of Children (6-15 years) not enrolled in School and Illiteracy Rates (Percent of 12-15 Years) by Poverty and Location, 2005

\begin{tabular}{c|c|c|c|c}
\hline \hline \multirow{2}{*}{} & \multicolumn{2}{|c|}{$\begin{array}{c}\text { Children (6-15 y.o.) Not } \\
\text { Enrolled in School }\end{array}$} & \multicolumn{2}{c}{$\begin{array}{c}\text { Illiteracy Rates } \\
\text { (Percent of Children 12-15 y.o.) }\end{array}$} \\
\cline { 2 - 5 } & Boys & Girls & Boys & Girls \\
\hline \hline Urban: & & & & 12 \\
Poor & 12 & 14 & 12 & 2 \\
Non-Poor & 4 & 3 & 3 & 4 \\
All Urban & 5 & 5 & 5 & 25 \\
Rural: & 11 & 23 & 11 & 10 \\
Poor & 6 & 9 & 6 & 15 \\
Non-Poor & 8 & 13 & 8 & \\
All Rural & & & & \\
\hline \hline
\end{tabular}

Source: World Bank (2007), Arab Republic of Egypt Poverty Assessment Update, Main Report, 16, September, World Bank.

The rates of illiteracy of poor and non-poor children in rural Upper Egypt were 2.2 times and 1.6 times their corresponding rates in rural Lower Egypt. Furthermore, in rural Upper Egypt, girls, whether poor or non-poor, were lagging behind boys in literacy (by more than two times).

An inclusive school must offer possibilities and opportunities for a range of working methods and individual treatment to ensure that no child is excluded from companionship and 
participation in school. Thus, as noted earlier, perceiving the process of education as an inclusive system provides a shift from seeing the child as a problem to seeing the education system as the problem that can be solved through inclusive approaches. Inclusive education of good quality, therefore, is the best means to overcome future learning deficiencies among the youth and the adults. In today's situation, however, private efforts must also be made to ensure appropriate education and training programs using different modalities for those who have so far been deprived.

\section{c. Inclusive Curricula}

Inclusive curricula include:

1- Cohesive transitions and articulations of the curriculum between the early primary, elementary and secondary stages of education to prevent drop-outs from one stage to another and ensure retention.

2- Curricular changes in order to support flexible learning and assessment.

\section{d. Teachers and Teacher Education}

3- The quality of public education in Egypt needs to be improved, especially at the primary and secondary levels, which are of most relevance to the poor. Among the most wellknown determinants of low quality education are inadequately qualified teachers, overcrowded classes, insufficient teaching time, multiple shifts, maltreatment of pupils by teachers, rote memorization techniques, and lack of libraries.

4- Teachers' proficiency in Egypt is rated lower than that of the teachers in similarly-situated countries such as Chile, Indonesia, Jordan and Thailand, especially teachers at primary and secondary schools.

\section{e. Resources and Legislation}

- National legislation should be changed and revised in order to be able to incorporate the techniques and notions of inclusive education.

- International agreements should be signed, ratified and reflected in national legislation.

- Budgetary allocations for inclusive education should be equitable, transparent, accountable and efficient.

\section{f. Literacy and Adult Education:}

There is a high correlation between poverty and illiteracy (UNDP 2008) with rural areas, especially in Upper Egypt, identified as the most vulnerable. According to the recent and comprehensive Survey of Young People in Egypt (SYPE) of 2010, among those who come from the poorest households, $29 \%$ never enrolled in school, and $24 \%$ of those who did dropped out before finishing basic education. In the age bracket 25-65 years, illiteracy is as high as $40 \%$. The illiteracy rate in rural areas reaches $62 \%$ compared to $27 \%$ in urban areas. Furthermore, the female illiteracy rate is greater than the male illiteracy rate, reaching 69\% for females and $31 \%$ for males according to the UNESCO/Egypt National Report on Literacy and Adult Education (2008). The number and rate of female illiteracy is generally more extensive in rural than urban areas.

Adult education programs should not just target literacy but should also promote contemporary thought, critical thinking, adaptation to the everyday-changing marketplace, tolerance and acceptance of the other, and integration with the technological developments of this era. These goals are likely to directly affect the content and method of teaching. 
Targeting Poverty through Inclusive Education in Egypt...

Institutions which are responsible for adult education need to deploy specific criteria and standards to upgrade quality and direct more attention to specific groups and deprived areas. Faculties of education and teacher-training colleges at universities must give more space to adult education. Overall, there is a need to stress the principles of equality and nondiscrimination and to develop pedagogical and implementation frameworks that would better reflect the interests of different social categories.

\section{III- The Role of Inclusive Education on Poverty:}

\section{1- Introduction: Poverty and Inclusive Education in Egypt}

Education is the corner stone of economic and social development and achievement. Also, there is a close correlation between education and income level. Education generally helps to improve the social conditions of the society's members who are enrolled in the socalled mass education element of equality (People's Council's General Committee 2000). It is well known that economic growth is a necessary but not sufficient condition to reduce poverty. Thus, policy makers have to understand the factors that help redistribute the outcomes of economic growth effectively (Anttila, 2005).

\section{2- The Relationship between Education and Poverty}

\section{2-1- Poverty and Education: General Considerations}

Figure 1 shows a clear association between levels of education and income. As levels of education rise, the probability of being poor declines (see Figure1). For example, the chances of being poor if one has a university education are much less (around 2 percent) than if one is illiterate (around 24 percent).

The association between education and income can also be considered from another perspective. Among poor individuals and households, there is a clear sorting by educational attainments, with a large fraction having little or no education and progressively smaller fractions having higher education:

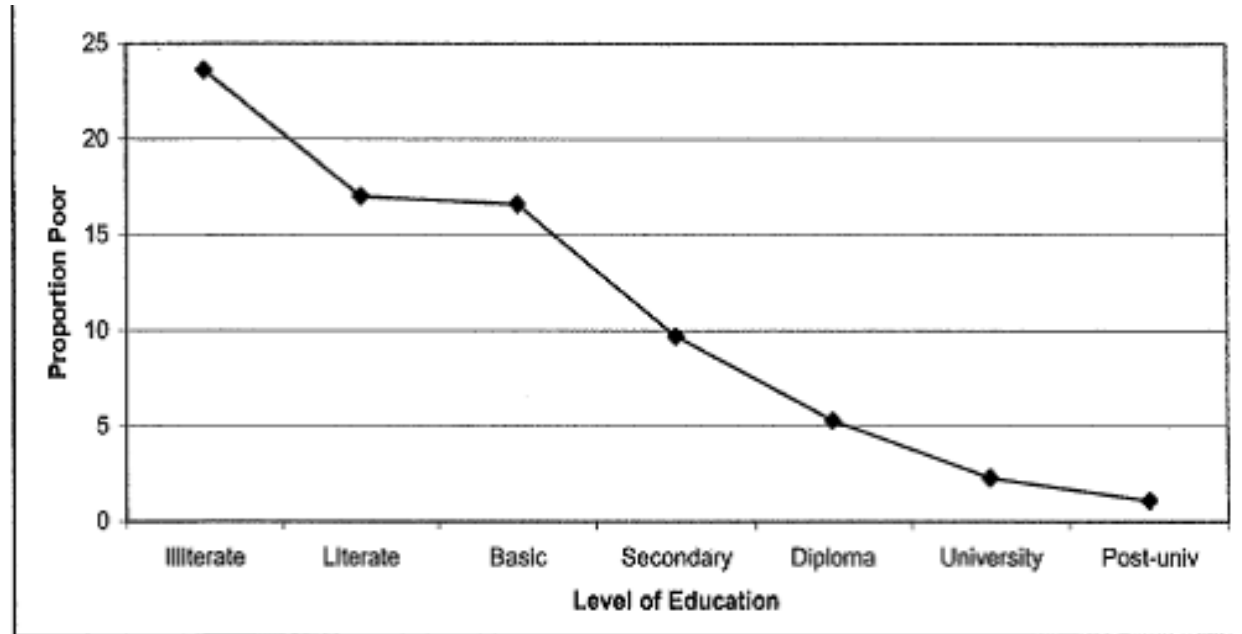

Source: World Bank (2007) World Bank (2007), Arab Republic of Egypt Poverty Assessment Update, Main Report, 16, September, World Bank.

Figure 1: Chance of Being Poor by Level of Education 


\section{2-2- The Role of Education in Reducing Poverty}

Education has a significant impact on the behavior of individuals, their qualifications and their chances in society, and this effect, in turn, is reflected in overcoming poverty and, consequently, its impact on the individual's income. Henceforth, education could be the best solution in the long term to the problem of poverty in the developing world. With the passage of time, according to some experts, the education of children, especially girls, is the key to end global poverty. The skills of reading and writing develop the child's thinking abilities and communication skills. More importantly, education helps children from poor families to escape poverty because each year the child spends in education is likely to raise the wages of the adult by on average 10\%, both for boys and girls (UNESCO_and education, 2011).

Therefore education plays an important role not only in supporting the individual to increase his/her income, but also in shaping the individual's behavior and decisions which, in turn, helps him/her satisfying various basic needs. It can be concluded that the desire to provide a society's individuals with educational skills has a profound influence on these individuals' ability to work and produce.

\section{2-3- The Nature of the Relationship between Poverty and Education}

Egypt has a high record in providing education for its citizens. This is shown by the steadily rising attainments in school admissions in the country (World Bank 2004b). The primary enrolment rates rose from 73 percent to 96 percent and secondary enrolment rates rose from 50 percent to 85 percent, a performance that is among the best in the Middle East as well as among lower middle income countries. Nevertheless, many challenges remain, especially if one considers the relationship between education and poverty.

Education is the most prominent correlate of poverty in Egypt and offers the most promising path out of it. The education-poverty relationship can be appreciated by reference to the following findings from the household budget survey and other sources which, generally speaking, show that the poor suffer from high illiteracy: 46 percent of the poor are illiterate and the situation is worse for poor females. This portion is also significant because there is evidence that illiteracy tends to be propagated across generations: illiterate households tend to have higher proportions of illiterate children. Moreover, rates of return are low for basic and secondary education, suggesting quality problems at these stages.

The indirect costs of education can be burdensome for poor families. For example, the income foregone by attending secondary school amounts to the cost of kindergarten education which, unlike other levels of education, is not free of tuition charges. This means that children from poor families are likely to join primary education later than those from non-poor families. Indeed, the lowest kindergarten enrolment rates are found in the poorest governorates, a fact that may reflect both the high costs of kindergarten tuition and the lack of kindergarten classes in these governorates.

The World Bank provided an analysis of four countries (Egypt, Jordan, Morocco, and Yemen) using a common methodology. The results reflect generally low rates of return on education. These estimates reveal that education is not a high-yielding investment in Middle Eastern and North African countries. 
Targeting Poverty through Inclusive Education in Egypt...

\section{2-4- Public Expenditure on Education}

Regarding the role of spending on education attainment, we find that public spending on education in the Middle East and North Africa actually decreased as a share of GDP and on a per capita basis. For instance, the share of the budget that is devoted to the education sector in Egypt has increased significantly from around 5 percent of the government budget in the early 1990s to about 12 percent currently. This is not far from the average for lower middle income countries. However, public expenditure on education declined, from $19.5 \%$ in 2002 to $11.5 \%$ in 2006 , as a percentage of total expenditure, and from $5.2 \%$ to $3.8 \%$, as a percentage of GDP.

There are many procedures that can be considered in order to redistribute the portion of expenditure devoted to education in Egypt. First, it may be possible to redirect funds from nonteaching tasks to teaching tasks within the budgets already provided to basic and secondary schools. Second, it may be worth considering reducing the share of tertiary facilities within the educational budget and increasing the share of basic and secondary schools (UNDP, 2008). Lastly, the dramatic deterioration in the quality of public education contributed to the creation of a generation of young Egyptians who are not well prepared for the job market.

Table No. 8

Public Expenditure on Education in 2010

\begin{tabular}{l|c|c}
\hline \hline & \% of GDP & \% of Total Government Expenditure \\
\hline \hline Brazil & 5.4 & - \\
\hline Egypt & 3.8 & 11.9 \\
\hline Israel & 5.9 & 13.7 \\
\hline Malaysia & 5.8 & 18.9 \\
\hline Middle East \& N. Africa & 4.8 & 20.0 \\
\hline Euro area & 5.5 & 11.5 \\
\hline \hline
\end{tabular}

Source: World Bank (2012) WORLD DEVELOPMENT, Washington, D.C., USA

The previous table shows low Public expenditure on education in Egypt compared with other states.

Finally, with regard to the quality dimension, the information presently available suggests that, although it is not possible to assert that the quality of education declined, it is true that education quality must be improved to cope with the challenges of a more competitive global environment in the future.

\section{3- Reducing Costs of Attending for the Poor}

Programs that help defray certain costs of schooling should be developed. Among measures that would accomplish this task are:

a. Stipends for poor children. Stipends could be provided to children from families identified as poor (through some credible means-testing mechanism) to cover the direct costs of schooling (including kindergarten or early childhood education). There have already been some successful experiences in this regard in Egypt. Under the EEP, some targeted subsidy programs have been developed on a pilot basis. These have helped reduce drop-out and repetition rates among students from poor families. 
b. Reducing the need for private tutoring. Group and individual private tutoring accounts for a significant portion of private expenditures on education. This is needed because of the necessity to prepare for the general secondary level examination required in order to gain access to higher education.

c. Establishing more schools and classes. Despite the good progress in targeting school building programs at underserved areas, much remains to be done. As shown earlier, poorer governorates have far fewer classrooms for their school-age population than richer governorates. Accordingly, the effort to provide more schools to the poor should continue. In particular, private efforts should be made to increase the number of kindergarten classrooms so that schooling can start earlier for the poor. Benefit-to-cost ratios of kindergarten expansion in Egypt have been estimated at 2.3 and higher (World Bank, 2002).

d. Reducing indirect costs. In some rural communities, indirect costs arising from children being in school rather than at work may be quite substantial. In such cases, adjusting the school calendar to avoid having children in school during peak periods of labor demand (e.g., during a particular season), may be advisable.

e. Making schools more accessible to girls. In order to make schools more accessible to girls, it would be useful to take such measures as: locating schools near villages and thereby eliminating the problem for young girls having to walk long distances to get to schools; staffing schools with female teachers; and developing gender sensitive curricula and teacher training.

\section{4- Policies for meeting the challenge}

There is a dire need to focus on policies and practices that will develop a functional learning system. Our policy must be focused on the goals of student access and success, workforce readiness, research and development infrastructure, literacy, and essential disciplines. There are many issues that need to be addressed in order to appropriately position inclusive education in the policy cycle. The suggested actions present a holistic approach to bringing about change in the entire education system and entail high cooperation among many actors to achieve this purpose (Jim Goodnight 2010)

\begin{tabular}{|c|c|c|}
\hline & $\begin{array}{c}\text { Desired } \\
\text { Strategic } \\
\text { Orientation }\end{array}$ & Suggested Action Plan Ideas \\
\hline $\mathrm{A}$ & $\begin{array}{l}\text { Ensure access } \\
\text { to education } \\
\text { and training }\end{array}$ & $\begin{array}{l}\text { - Making education and training widely available at anytime and anywhere } \\
\text { (on-site, online and just-in-time). We need to be open to supporting new } \\
\text { models, different providers, and broad-based primary, secondary, } \\
\text { postsecondary and business partnerships that increase educational access. } \\
\text { - Fostering lifelong learning by providing flexible and varied } \\
\text { educational opportunities, and access to the necessary knowledge and } \\
\text { skills at any point in an individual's lifetime. } \\
\text { - Investing in pre-primary education programs, which have historically } \\
\text { provided the best return on investment. The earlier a child learns to } \\
\text { read, the better. } \\
\text { - Ensuring access to higher education for all members of the society by } \\
\text { providing the economically disadvantaged with government-supported } \\
\text { financial aid. }\end{array}$ \\
\hline
\end{tabular}


Targeting Poverty through Inclusive Education in Egypt...

\begin{tabular}{|c|c|c|}
\hline & $\begin{array}{c}\text { Desired } \\
\text { Strategic } \\
\text { Orientation }\end{array}$ & Suggested Action Plan Ideas \\
\hline $\mathbf{B}$ & $\begin{array}{l}\text { Continual } \\
\text { assessment of } \\
\text { education } \\
\text { performance } \\
\text { in relation to } \\
\text { goals }\end{array}$ & $\begin{array}{l}\text { - Creating strong accountability and transparency in our education systems. } \\
\text { - Putting accountability systems in place that will provide educators with } \\
\text { insights on what happens to students after they complete their education, } \\
\text { transfer to other universities or take jobs and will allow to discern whether } \\
\text { these students have the necessary skills to gain and maintain employment. } \\
\text { - Supporting policy that rewards evidence-based educational transformation. } \\
\text { - Enabling governments and educators with the tools that will allow } \\
\text { them to gather data analyze that data and create policies based on deep } \\
\text { knowledge of which policies will create the desired outcomes. }\end{array}$ \\
\hline $\mathbf{C}$ & $\begin{array}{l}\text { Implement } \\
\text { consistent } \\
\text { policies that } \\
\text { will ensure } \\
\text { workforce } \\
\text { availability }\end{array}$ & $\begin{array}{l}\text { - Enacting a "human capital" tax credit for employers who provide } \\
\text { training and education for workers. This will have the dual effect of } \\
\text { lowering the public cost for training and education while providing a } \\
\text { motivation for employers to commit to lifelong learning. } \\
\text { - Developing a curriculum that supports essential disciplines like } \\
\text { science, technology and engineering while addressing the basic need } \\
\text { for global literacy. } \\
\text { - Providing scholarship assistance, teachers' institutions and mentoring } \\
\text { programs to encourage more participation from those with experience } \\
\text { in business or civil society to become teachers. } \\
\text { - Creating a labor policy that has enough flexibility to allow for necessary } \\
\text { - Porker redeployment. } \\
\text { activities. }\end{array}$ \\
\hline $\mathbf{D}$ & $\begin{array}{l}\text { Advance } \\
\text { innovative } \\
\text { research and } \\
\text { development }\end{array}$ & $\begin{array}{l}\text { - Concentrating government funding on basic research. } \\
\text { - Ensuring research results are open and available to the public through online } \\
\text { databases that allow access to such data for companies and academics. } \\
\text { - Allowing university researchers to license and retain the intellectual } \\
\text { property they create in order to found a commercial venture. }\end{array}$ \\
\hline $\mathbf{E}$ & $\begin{array}{l}\text { Promote } \\
\text { social, state } \\
\text { and global } \\
\text { business/educ } \\
\text { ation } \\
\text { partnerships }\end{array}$ & $\begin{array}{l}\text { - Working cooperatively to enhance the use of technology in learning } \\
\text { and to develop the information technology skills necessary for the } \\
\text { workplace. Ensuring that skills become a part of the education and } \\
\text { lifelong learning curricula. } \\
\text { - Providing incentives for business to participate in school mentor } \\
\text { programs, "adopt a school" programs or community-based initiatives. } \\
\text { - Embracing best practices from other regions of the world that have } \\
\text { hard data to substantiate results. } \\
\text { - Fostering a culture of innovation and reward risk-taking at all levels. }\end{array}$ \\
\hline $\mathbf{F}$ & $\begin{array}{l}\text { Enhance } \\
\text { access and } \\
\text { reduce costs } \\
\text { of education } \\
\text { for the poor } \\
\text { by }\end{array}$ & $\begin{array}{l}\text { Access-enhancing approach in various locations. } \\
\text { Adding kindergarten classes to public schools and make them available } \\
\text { to the poor free of tuition charges. } \\
\text { Offering conditional stipends for attendance, making more schools or } \\
\text { classrooms available in underserved areas and adding free kindergarten } \\
\text { facilities where appropriate }\end{array}$ \\
\hline
\end{tabular}




\begin{tabular}{|c|c|c|}
\hline & $\begin{array}{c}\text { Desired } \\
\text { Strategic } \\
\text { Orientation }\end{array}$ & Suggested Action Plan Ideas \\
\hline $\mathrm{G}$ & $\begin{array}{l}\text { Improve } \\
\text { quality of } \\
\text { basic and } \\
\text { secondary } \\
\text { education for } \\
\text { the } \\
\text { poor, }\end{array}$ & $\begin{array}{l}\text { - In selected governorates, implementing a program to change school } \\
\text { and teacher performance assessment systems from an inspection basis } \\
\text { (as currently done) to an evaluation basis and providing monetary } \\
\text { rewards to high performing schools and teachers. } \\
\text { - Designating selected rural schools as technology pilots and provide } \\
\text { sufficient budgets to equip them with telephone lines, computer } \\
\text { equipment and software. } \\
\text { - Improving data quality and frequency of data collection in a cost } \\
\text { effective manner. } \\
\text { - Instituting monitoring mechanisms to track job placements of } \\
\text { graduates. } \\
\text { - Improving teachers' skills, instituting evaluation processes that better } \\
\text { reflect teachers' performance, and improving technology skills of both } \\
\text { teachers and students. }\end{array}$ \\
\hline
\end{tabular}

\section{IV-Conclusion and Recommendations:}

\section{IV-1- Conclusion:}

In conclusion, more than half of the population in rural areas remains poor and near poor - a share which has remained stable over the last 15 years. While poverty in Egypt appears to be shallow (the monetary deficit of a poor person is just above one Egyptian pound), there are pockets of deep poverty, particularly in rural areas, that are of prime concern to the present study. The recent increase in poverty was not evenly distributed among the poor, but rather the extremely poor were affected the most. The poorest took the hardest hit, with extreme poverty increasing from 3.8 to 6.7 percent.

Poverty is higher in rural areas than in urban areas, and particularly high in rural Upper Egypt. Not only is the risk of being poor higher in rural areas (26.8 percent) than in urban areas (13.4 percent, excluding metropolitan areas), but poverty is also more severe in rural areas.

The decline in quality of education is perhaps the most serious challenge to poverty reduction. Because of rising enrollments and limited resources for education, at the primary and secondary stages schools have enlarged class capacities with a consequent negative impact on the quality of education and future employment prospects of youth who are illprepared for the labour market. The contemporary education system has also not promoted a curriculum that falls in line with the demands of the labor market and it has exacerbated inequalities between the well-off who can afford private education and the poor who cannot.

Furthermore, the lack of understanding, awareness and support in society about inclusive education needs to be addressed through advocacy and dialogue at regional and national levels. The present study shows that inclusive education of good quality is the best means to overcome future learning deficiencies among the youth and the adults. In order to overcome the problems of the current educational system, however, private efforts must also be made to 
ensure appropriate education and training programs use different modalities for those young people and adults who have so far been deprived.

The quality of public education in Egypt needs to be improved, especially at the basic and secondary levels that are of most relevance to the poor. Among the determinants of low quality that are usually highlighted are inadequately qualified teachers, overcrowded classes, insufficient instructional time, multiple shifts, maltreatment of pupils by teachers, rote memorization techniques, and lack of libraries. The research reveals also that education is the most prominent correlate of poverty in Egypt and offers the most promising path out of it.

\section{IV-2- Recommendations:}

The study recommends the adoption of an educational policy sensitive to the poor and that takes into account the following:

1- Directing more resources to basic education.

2- Increasing investment expenditure on education in order to achieve justice and efficiency in spending.

3- Allocating more resources to rural areas.

4- Improving the quality of the educational process.

In addition, there are some proposals for actions at the micro level that would make education more accessible to the poor. These include:

- Reducing school fees for primary education and providing some technical skills useful to the poor, especially for girls;

- Directing attention to basic education due to its higher social returns, as well as providing an opportunity for those who are able to continue after basic education;

- Enhancing the role of social programs that are concerned with the problems of street children and the expansion of technical training centers and vocational rehabilitation. 


\section{References}

- Achcar, G. (2009), "Egypt's Recent Growth: An Emerging Success Story", Development Viewpoint, SOAS (http://eprints.soas.ac.uk/7332/1/DevelopmentViewpoint22.pdf.).

- Anttila, P. (2005). Finland as a Knowledge Economy: Elements of Success and Lessons Learned. Washington, D.C.: World Bank.

- Goodnight, Jim. (2010). Educating for Global Competitiveness, A White Paper on Education in the $21^{\text {st }}$ Century by, CEO and Co-founder of SAS, U.S.A.

- Keller, Jennifer. (2011). Inclusive Growth Diagnostic Analysis New Approaches to Determining Country Priorities. The World Bank, September 28,Nairobi, Kenya.

- Kheir-El-Din, Hanaa and Heba El-Laithy. (2006). An Assessment of Growth, Distribution and Poverty in Egypt: 1990/91-2004/2005, Working Paper No. 115, December 2006) ECES.

- Klau, A. (2010). Impact of the Economic Crisis on Trade, Foreign Investment and Employment in Egypt. International Labour Organization (ILO), February.

- Ministry of Education. (2007). National Strategic Plan, For Pre-university Education Reform In Egypt, 2007/2008 - 2011/2012, Arab Republic of Egypt.

- MOE. (2007). National Strategic Plan for Pre-university Education Reform in Egypt. Annexes, World Economic Forum USA Inc., The Financial Development Report, 2012, New York, USA.

- Opertti, R. and C. Belalcázar. ( 2008). Trends in Inclusive Education at Regional and Interregional Levels: Issues and Challenges. Geneva, IBE. P. 16. Participation, Development, and Inclusion. NewYork: UNICEF.

- Peters, Susan J. (2003). Inclusive Education: Achieving Education for All by Including Those With Disabilities and Special Education Needs, Prepared for the Disability Group, The World Bank, April, 30.

- Sahlberg, P. (2006). "Education Reform for Raising Economic Competitiveness", Journal of Educational Change, Springer.

- UNDP. (2008). United Nations Development Programme Regional Centre for Arab States. Cairo, Egypt.

- UNDP. (2010). Egypt Human Development \{76\} Report, The Egypt Human Development Report 2010 is a Major Output of the Human Development Project, Executed by the Institute of National Planning, Egypt, under the Project Document EGY/01/006 of Technical Cooperation with the United Nations Development Programme).

- UNDP. (2010). Egypt's Progress towards Achieving the Millennium Development Goals.

- UNDP. (2010). The Ministry of Local Development, United Nations Development Programme, and the World Bank, Consultancy for Up Stream Poverty and Social Impact Analysis (PSIA) for Egypt's Solid Waste Management Reform, Final Report, December.

- UNESCO. (2009). Undated Policy Guidelines on Inclusion in Education. United Nations Educational, Scientific and Cultural Organization, Paris, France.

- UNESCO_and Education. ( 2011). Everyone Has the right to Education. United Nations Educational, Scientific and Cultural Organization, Paris, France.

- UNICEF. (2009). Meeting the Needs of Children and Young People in Implementing the Convention on Rights of Persons with Disabilities. Remarks by Hilde F. Johnson, UNICEF Deputy Executive Director, $3^{\text {rd }}$ September.

- UNICEF.( 2007). Children with Disabilities: Ending Discrimination and Promoting 
- World Bank. (2002). Arab Republic of Egypt Poverty Reduction in Egypt Diagnosis and Strategy. (In Two Volumes) Volume II: Annex Tables. June 29, 2002, Social and Economic Development Group Ministry of Planning. Middle East and North Africa Region Government of the Arab Republic of Egypt.

- World Bank. (2004). Arab Republic of Egypt, A Poverty Reduction Strategy for Egyp, September 25, Ministry of Planning Government of the Arab Republic of Egypt, Social and Economic Development Group, Middle East and North Africa Region,The World Bank.

- World Bank. (2005). Expanding Opportunities and Building Competences of Young People: A New Agenda for Secondary Education. World Bank, D.C.: Washington. SAHLBERG Human Development, World Bank, 1818 H Street Washington, D.C.

- World Bank. (2007). Arab Republic of Egypt Poverty Assessment Update. Main Report, 16, September, World Bank.

- World Bank. (2011). Report No. 60249-EG. Arab Republic of Egypt Poverty in Egypt 2008-2009 With Standing the Global Economic Crisis. Social and Economic Development Group, World Bank Middle East and North Africa Region, Washington, D.C.

- World Bank. (2012). World Development. Washington, D.C., USA

- World Economic Forum. (2012). The Financial Development Report. Geneva, Switzerland

- World Economic Forum. (2012). The Global Competitiveness Report 2012-2013. Geneva World Economic Forum (Opinion Survey). 